\title{
Mixed Embryonal Carcinoma and Teratoma
}

National Cancer Institute

\section{Source}

National Cancer Institute. Mixed Embryonal Carcinoma and Teratoma. NCI Thesaurus.

Code C3756.

A germ cell tumor characterized by the presence of an embryonal carcinoma component and a teratoma component. 